\title{
Vuorovaikutus oppimisen kohteena lukiossa - kirja-arvio kolmesta äidinkielen ja kirjallisuuden uudesta oppikirjasarjasta
}

\section{Suvi-Tuuli Murumäki}

\author{
Viittausohje: \\ Murumäki, S-T. (2021). Vuorovaikutus oppimisen kohteena lukiossa - kirja-arvio kolmesta äidinkielen ja \\ kirjallisuuden uudesta oppikirjasarjasta. Prologi - Viestinnän ja vuorovaikutuksen tieteellinen aikakauslehti, \\ 17(1), 70-73. https://doi.org/10.33352/prlg.110842 \\ To cite this article: \\ Murumäki, S-T. (2021). Vuorovaikutus oppimisen kohteena lukiossa - kirja-arvio kolmesta äidinkielen ja \\ kirjallisuuden uudesta oppikirjasarjasta [Learning communication in upper secondary school - Book review \\ of three new series of study books]. Prologi - Journal of Communication and Social Interaction, 17(1), \\ 70-73. https://doi.org/10.33352/prlg.110842
}

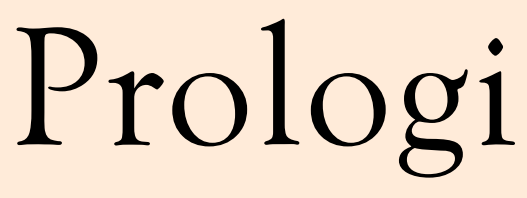

- Viestinnän ja vuorovaikutuksen
tieteellinen aikakauslehti
journal.f/prologi/

ruotsiksi: Prologi - Tidskrift för Kommunikation och Social Interaktion englanniksi: Prologi - Journal of Communication and Social Interaction

Julkaisija: Prologos ry.

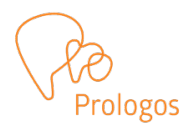

Avoin julkaisu / Open Access

ISSN 2342-3684 / verkko

ISSN 1795-7613 / painettu versio 


\section{Kirja-arvio}

Prologi, 17(1)

$70-73$

https://doi.org/10.33352/prlg.110842

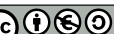

\section{Vuorovaikutus oppimisen}

kohteena lukiossa -

kirja-arvio kolmesta äidinkielen ja

kirjallisuuden uudesta oppikirjasarjasta

\section{Suvi-Tuuli Murumäki}

FM, puheviestinnän yliopisto-opettaja

Humanistinen tiedekunta, Helsingin yliopisto

suvi-tuuli.murumaki@helsinki.fi

vastaanotettu 4.6.2021 / hyväksytty 6.8.2021 / julkaistu 27.8.2021

ASIASANAT: lukio, oppikirja, oppiminen, viestintä, vuorovaikutus

Arvioinnin kohteena ovat vuorovaikutusmoduulien materiaalit oppikirjasarjoissa Loisto, Särmä ja Ä̈̈ni.

Lukion opetussuunnitelman perusteet uudistuivat, ja ne otetaan opetuskäyttöön elokuussa 2021. Äidinkielen ja kirjallisuuden opetussuunnitelmaa uudistettaessa yksi tavoite oli vuorovaikutuksen opetuksen vahvistaminen. Vuorovaikutukseen liittyviä oppimistavoitteita ja -sisältöjä ei määrällisesti juuri lisätty, mutta niitä päivitettiin, monipuolistettiin ja syvennettiin. Sisällöllisessä päivityksessä ryhmäviestintätaitoihin ja ryhmän vuorovaikutuksen ymmärtämiseen kytkeytyviä oppimistavoitteita tarkennettiin ja muutettiin vaativammiksi. Aiempaa keskeisempään rooliin nostettiin myös kuuntelemisen, vuorovaikutusetiikan, esiintymisjännityksen sekä palautteenantamisen ja vastaanottamisen teemoja. Erityistä painoarvoa annettiin vuorovaikutustilanteiden ja -suhteiden ymmärtämiselle, havainnoinnille ja analysoimiselle.

Vuorovaikutuksen opetuksen profilinnostoon näyttää vaikuttaneen myös koko lukion opetussuunnitelmaa koskeva rakenteellinen muutos; kurssirakenteen korvaaminen temaattisilla, vapaasti yhdisteltävillä moduuleilla. Moduulirakenteen takia aiemmin eri kursseille hajautetut 
vuorovaikutuksen oppimistavoitteet ja -sisällöt koottiin omiksi moduuleikseen. Kaksi yhden opintopisteen vuorovaikutusmoduulia (ÄI3 Vuorovaikutus I ja ÄI7 Vuorovaikutus II) saatiin kaikille opiskelijoille pakolliseksi ja yksi kahden opintopisteen moduuli (ÄI9 Vuorovaikutus III) valinnaiseksi. Osa vuorovaikutukseen mutta samalla myös lukemiseen ja kirjoittamiseen liittyvistä sisällöistä (esimerkiksi argumentointi ja retoriset keinot) sisällytettiin osaksi muita äidinkielen ja kirjallisuuden moduuleita.

Uudistusta koskevassa - sekä kriittisessä että kiittävässä - keskustelussa on vaikuttanut siltä, että vuorovaikutussisältöjen kokoaminen omiksi (pakollisiksi) moduuleikseen on nostanut tietoisuutta vuorovaikutusosaamisen merkityksestä ja sen kuulumisesta kiinteästi äidinkieli ja kirjallisuus -oppiaineen tavoitteisiin. Yllättävän moni on tuntunut vasta moduuliuudistuksen myötä havahtuvan siihen, että vuorovaikutusta todella saa - tai on pakko - lukiossakin opettaa. Tämä on ollut toisaalta ilahduttavaa, toisaalta hämmentävää siksi, että vuorovaikutukseen liittyviä oppimistavoitteita ja -sisältöjä on ollut lukion opetussuunnitelmien perusteissa huomattavan pitkään. Vuorovaikutuksen aseman vahvistamiseksi on tehty pitkäjänteistä työtä useissa aiemmissa opetussuunnitelmauudistuksissa.

Tämä kirja-arvio kohdistuu kolmeen uuden opetussuunnitelman mukaiseen äidinkielen ja kirjallisuuden oppikirjasarjaan - Editan Ääni, Otavan Särmä ja Sanoma Pron Loisto - niiltä osin, kuin ne käsittelevät vuorovaikutusta. Kirjasarjat ovat rakenteeltaan erilaisia. Äänessä oppiaineen kullekin moduulille on oma oppikirjansa, johon sekä moduulin tietosisältö että oppimista tukevat tehtävät on koottu. Särmässä ja Loistossa on taas yksi laaja, koko äidinkielen ja kirjallisuuden lukio-oppimäärää käsittelevä tietokirja, johon esimerkiksi vuorovaikutuksen, kirjallisuuden, kirjoittamisen ja lukemisen tietosisällöt sijoittuvat omina osinaan. Tietokirjan lisäksi Särmässä ja Loistossa on joko yksittäisille moduuleille tai parin moduulin yhdistelmille suunnattuja tehtävävihkoja.

Arvioitavanani on ollut Editan Äänestä Vuorovaikutus I -moduulin oppikirja. Sanoma Pron Loistosta ja Otavan Särmästä arvioin tietokirjan vuorovaikutus-osaa sekä Vuorovaikutus I -moduulin tueksi laadittua tehtävävihkoa.

Lukiessani näitä teoksia olen ollut iloinen ja ylpeä. Vaikka uunituoreet oppikirjat ovat paitsi rakenteeltaan, myös kirjoitustyyliltään ja laajuudeltaan erilaisia, niitä kaikkia yhdistää kaksi keskeistä asiaa. Ensinnäkin kirjoitustyöhön on kutsuttu mukaan vankkoja viestintätieteen asiantuntijoita. Toiseksi kirjoittajat ovat pyrkineet vahvasti seuraamaan opetussuunnitelman tavoitteita.

Laajimman, syvimmän ja kunnianhimoisimman kattauksen vuorovaikutuksesta näyttäisi tarjoavan Editan Ääni. Kirjoitan tämän pienellä varauksella, sillä kirjoitushetkellä Äänen Vuorovaikutus II ja III -moduulien oppikirjat eivät vielä ole ilmestyneet. Siten arvioni perustuu vasta Vuorovaikutus I -moduulin oppikirjaan Ääni 3. Pelkästään tässä yhden opintopisteen moduulia varten laaditussa oppikirjassa on lähes 90 sivua tietoa, harjoituksia sekä itsearviointi-, havainnointi- ja analyysitehtäviä vuorovaikutuksesta.

Ääni 3 käsittelee vuorovaikutuksen ja vuorovaikutusosaamisen perusteita monipuolisesti ja innostavasti. Vuorovaikutus I -moduulin keskeisintä teemaa eli ryhmäviestintää käsitellään erittäin kattavasti ja konkreettisesti. Kirja tarjoaa onnistuneen katsauksen myös esimerkiksi viestijäkuvaan, viestintärohkeuteen, kuunteluun, palautteen antamiseen ja 
vastaanottamiseen, vaikuttamiseen, teknologiavälitteiseen vuorovaikutukseen sekä vuorovaikutussuhteisiin ja niiden dynamiikkaan. Kirjassa esitellään jopa viestinnän teorioita ja oppija pääsee kurkistamaan epävarmuuden vähentämisen, sosiaalisen läpäisyn ja vuorovaikutussuhteiden jännitteisyyden teorioihin. Lisäksi oppijalle tarjotaan havainnollisia ja selkeitä ohjeita vuorovaikutuksen analysoimiseen. Vaikka oppikirjan teksti on onnistuneesti lukiolaiselle kohdennettua, siitä välittyy erittäin vahva asiantuntemus ja tutkimusperustaisuus.

Lukijan kokemusta Ääni 3:n monipuolisuudesta korostaa se, että tietoteksti ja tehtävät on koottu samaan oppikirjaan. Tehtävät ovat kiinnostavia, aihetta syventäviä ja nuorten arkeen, esimerkiksi sosiaaliseen mediaan, tavoitteellisesti kiinnittyviä. Monin paikoin Ääni 3 itse asiassa kirkkaasti ylittää opetussuunnitelman Vuorovaikutus I -moduulin tavoitteet syventäen ja monipuolistaen oppijan kuvaa vuorovaikutuksesta. Syntyy ilahduttava vaikutelma siitä, että kustantaja on antanut kirjoittajille tilaa ja tila on myös käytetty. Laajuudessaan Ääni 3 saattaa olla hiukan haastava osalle oppijoista, mutta innostuneen oppijan materiaalina se on upea. Näkisin, että se voi hyvin toimia myös lukiolaisen siltana viestinnän yliopisto-opintoihin. Toivottavasti Äänen oppikirjasarjassa on valmisteilla yhtä hienot oppikirjat Vuorovaikutus II ja Vuorovaikutus III -moduuleille!

Sanoma Pron Loisto käsittelee vuorovaikutusta selkeästi suppeammin kuin Editan Ääni mutta kattaa kuitenkin pääosin opetussuunnitelman vuorovaikutusmoduuleiden oppimistavoitteet. Loiston käsikirjan vuorovaikutusosan (s. 88-113) teksti on napakkaa ja helposti lähestyttävää, joten lukija saa nopeasti hahmotetuksi peruskuvan vuorovaikutuksesta. Tiiviin ja selkeän käsittelyn saavat vuorovaikutusosaaminen, viestijäkuva, ryhmäviestintä ja ryhmävies- tintätaidot, vuorovaikutusetiikka, esiintyminen ja esiintymisjännitys sekä palautteenanto. Myös esiintymisen ja ryhmäviestinnän analysoimista ja arvioimista käsitellään. Erillinen tehtävävihko täydentää onnistuneesti kokonaisuutta ja kutsuu oppijaa pohtimaan vuorovaikutusta monipuolisten, nuoren arkeen kiinnittyvien kysymyssarjojen ja pohdintatehtävien avulla.

Loiston käsikirjan vuorovaikutusosaa lukiessani olisin kuitenkin kaivannut paikoin laaja-alaisempaa aiheen avaamista. Esimerkiksi käsiteltäessä viestintäkulttuurien eroja saattaisi olla hyödyllistä avata viestintäkulttuurin käsitettä enemmän ja laajentaa sitä selkeämmin koskemaan muutakin kuin kansallista kulttuuria. Olisin mielelläni nähnyt myös kuuntelun ja vaikkapa vuorovaikutussuhteiden dynamiikan tarkempaa käsittelyä.

Toisaalta tiiviys ja yksinkertaistaminen ovat Loiston vahvuus. Loiston teksti on todella lukijaystävällistä, selkeää ja helppoa. Se todennäköisesti kantaa mukanaan myös esimerkiksi oppimisvaikeuksista kärsivää tai kuormittunutta oppijaa - vahvuus, joka nykylukion uuvuttavuudessa on ilmeinen. Oppijan kannalta Loistossa antoisaa on myös se, että työelämän vuorovaikutusta käsitellään omana kokonaisuutenaan. Tarjolla on konkreettista ja työelämään siirtyvää nuorta aikuista varmasti hyödyttävää tietoa muun muassa kokouksissa ja neuvotteluissa toimimisesta sekä videotyöhakemuksen laatimisesta.

Otavan Särmässä tietokirjan vuorovaikutusosa (s. 248-299) on laajuudeltaan Äänen ja Loiston välimaastossa. Särmä seuraa erinomaisesti opetussuunnitelman linjoja ja uskaltaa Äänen tavoin laajentaa näkökulmiaan opetussuunnitelman tavoitteiden ja sisältöjen ulkopuolellekin. On esimerkiksi hienoa, että Särmä käsittelee viestintäherkkyyttä ja assertiivisuutta, vaikkei 
opetussuunnitelmateksti tätä suoraan vaadikaan.

Särmä tekee sopivan syvän, mutta samalla konkreettisen katsauksen muun muassa kuunteluun, palautteenantamiseen ja vastaanottamiseen sekä vuorovaikutusetiikkaan. Ryhmän vuorovaikutusta ja ryhmäviestintätaitoja avataan moniulotteisesti ja onnistuneesti. Sekä ryhmäviestinnän että esiintymisen havainnointiin ja analysointiin tarjotaan selkeät ohjeet. Esiintymistä käsittelevä osuus antaa lukijalle kattavaa ohjausta aina esiintymisen valmistelusta itse esiintymistilanteeseen ja esiintymisjännityksen ymmärtämiseen asti. Erityisen ilahduttavaa on se, että esiintymisen vuorovaikutusluonnetta, yleisön vastuuta ja kaikkien oikeutta tulla kuulluksi korostetaan.

Särmän tietokirjan vuorovaikutusosan teksti on helposti ymmärrettävää ja selkeää, mutta silti vahvan tutkimusperustaista. Kirjoittajien asiantuntemus ja kokemus välittyvät. Myös luettavanani olleen erillisen tehtävävihkon tehtävät ovat pääosin onnistuneita, joskin harjoituksiin liittyvät reflektointiohjeet voisivat kytkeytyä selkeämmin tietokirjan tarjoamaan teoriapohjaan ja olla hiukan kunnianhimoisempiakin. Tehtävävihkossa ihastustani herättävät kuitenkin esimerkiksi ne monipuoliset tavat, joilla vuorovaikutuksen ja kirjallisuuden oppimista integroidaan keskenään.
Kaikkein eniten pidän Särmässä sen kutsuvasta, lempeästä ja oppijan tueksi asettuvasta sävystä. Vuorovaikutusetiikka sekä itsen ja toisten arvostaminen kulkevat tietokirjan vuorovaikutusosaa läpileikkaavana teemana. Lukiessa syntyy olo, että hyvä ja eettinen vuorovaikutus ei ole vaikeaa tai vain joidenkin etuoikeus, vaan - aivan oikein - kaikkien omaa ja kaikkien vastuulla.

Loppusanoikseni haluan lämpimästi kiittää kaikkia arvioimieni vuorovaikutusosioiden kirjoittajia. Oppikirjatyö on opetussuunnitelmatyön tavoin täynnä erilaisia kompromisseja ja erilaisten toiveiden yhteensovittamista. Sen lisäksi se on huikean iso urakka. Upeaa, että olette tuoneet asiantuntemuksenne lukiolaisten käyttöön!

\section{Kirjallisuus}

Hakalin, M., Heikkonen, E., Kollin, L., Kotilainen, L., Lintunen, T., Mattila, N., \& Timonen, K. (2021). Loisto (käsikirjan vuorovaikutusosuus s. 88-113) sekä Tammela J.- M., \& Timonen, K. (2021). Loisto 3 tehtävävihko. Helsinki: Sanoma Pro.

Laaksonen, V., Martikainen, T., \& Sallinen, P. (2021). Ä̈̈ni 3. Helsinki: Edita.

Osola, K., \& Virtanen, I. (2021). Särma (tietokirjan vuorovaikutusosuus s. 248-299) sekä Kumenius, J., Kuohukoski, S., Marin, A., \& Mononen, S. (2021). Särmä tehtävävihko 2-3 (tehtävien vuorovaikutusosuus s. 68-99). Helsinki: Otava.

TITLE AND KEYWORDS IN ENGLISH:

Learning communication in upper secondary school - Book review of three new series of study books

KEYWORDS: communication, interaction, learning, study book, upper secondary school 